\title{
ANALISA PENGARUH KEDALAMAN POTONG DAN WAKTU PROSES PEMBUBUTAN KONVENSIONAL TERHADAP TEMPERATUR PAHAT, KONDISI PAHAT DAN KEKASARAN PERMUKAAN PADA BAJA ST41
}

\author{
Joko Nugroho \\ Teknik Mesin, Fakultas Teknik \\ Universitas Maarif Hasyim Latif, Sidoarjo, Indonesia \\ e-mail : joko-nugroho@student.umaha.ac.id
}

\begin{abstract}
ABSTRAK
Kunci dihasilkannya produk yang berkualitas diperoleh dari proses pemesinan yang dilakukan secara tepat, diantaranya adalah nilai kekasaran permukaan produk yang menjadi nilai ukur dan merupakan faktor yang penting untuk menentukan kualitas produk. Faktor-faktor yang menjadi pengaruh terhadap nilai kekasaran permukaan adalah kedalaman potong, kecepatan potong, kecepatan gerak pahat, kecepatan putar spendel, lama waktu pemesinan, pendingin, jenis benda kerja, jenis pahat, dan kondisi pemesinan, penelitian ini dilakukan untuk mengetahui pengaruh variasi kedalaman potong dan lama waktu pembubutan terhadap kondisi pahat dan tingkat kekasaran permukaan yang dihasilkan, menggunakan pahat hss dan bahan uji st41, pengujian ini dilakukan dengan 4 variasi kedalaman potong dan 2 variari waktu, variasi yang dilakukan akan dianalisa dan dikorelasikan dengan tingkat kekasaran yang dihasilkan, alat uji yang digunakan dalam uji kekasaran ini adalah Surface Roughness Tester Mitutoyo SJ-210. Penelitian ini akan menghasilkan tingkat kekasaran paling halus sebesar $2.217 \mu \mathrm{m}$ pada variasi perlakuan 15 menit dengan kedalaman potong $0.2 \mathrm{~mm}$.
\end{abstract}

Kata kunci: Baja st41, Kekasaran, Pahat

\section{PENDAHULUAN}

Dunia industri saat ini tidak dapat dipisahkan dari adanya proses permesinan, diantaranya pada proses pembubutan. Proses pembubutan adalah proses perautan atau pemotongan dengan menggunakan mesin bubut untuk menghasilkan bentuk silindris, dapat juga digunakan untuk membentuk ulir, proses bor dan membuat rata benda putar dengan cara meraut atau mengurangi ukuran benda kerja berputar pada cekam dengan pahat yang memiliki tingkat kekerasan melebihi benda kerja yang dibubut. Interaksi antara pahat dengan benda kerja Selama proses pembubutan berlangsung dimana pahat mengalami gesekan dan benda kerja terpotong. gesekan yang terjadi pada pahat mengakibatkan terjadinya panas. Panas sebagian besar juga terbawa oleh geram, sebagian lagi merambat melalui pahat dan sisanya mengalir melalui benda kerja menuju sekeliling chuck pencekam benda kerja, dengan suhu yang besar maka ujung pahat yang aktif akan mengalami perubahan dan juga akan berpengaruh pada kekasaran permukaan benda kerja.

Jenis perubahan kondisi yang akan dianalisa dalam tulisan ini adalah jenis perubahan berupa keausan ataupun segala jenis efek yang terjadi pada tepi pahat, untuk meminimalisir terjadinya keausan pahat dalam proses pembubutan ada beberapa hal yang perlu diperhatikan, diantaranya adalah gerak makan dan putaran spindel. Temperatur pemotongan juga mempunyai pengaruh yang besar terhadap umur pahat, oleh karene itu temperatur mempunyai hubungan terhadap keondisi pahat yang menjadi salah satu acuan dalam menentukan kondisi pahat tersebut.

Umur pahat merupakan salah satu faktor yang penting dalam memperkirakan pekerjaan pada pemesinan, kondisi pekerjaan pada proses pemesinan seperti kedalaman potong dan kecepatan putaran akan mempengaruhi rambatan temperature pada pahat, untuk itu perlu dilakukan pengujian analisa temperature pada pahat, Tulisan ini akan membahas tentang bagaimana pengaruh kedalaman potong dan lama waktu pembubutan terhadap temperature, keausan pahat dan kekasaran permukaan benda uji pada proses bubut manual atau konvensional dengan menggunakan pahat HSS dan benda uji baja st41.

\section{METODE PENELITIAN}

Pelaksanaan ini harus melalui beberapa prosedur pengujian sebagai berikut :

1. Observasi 


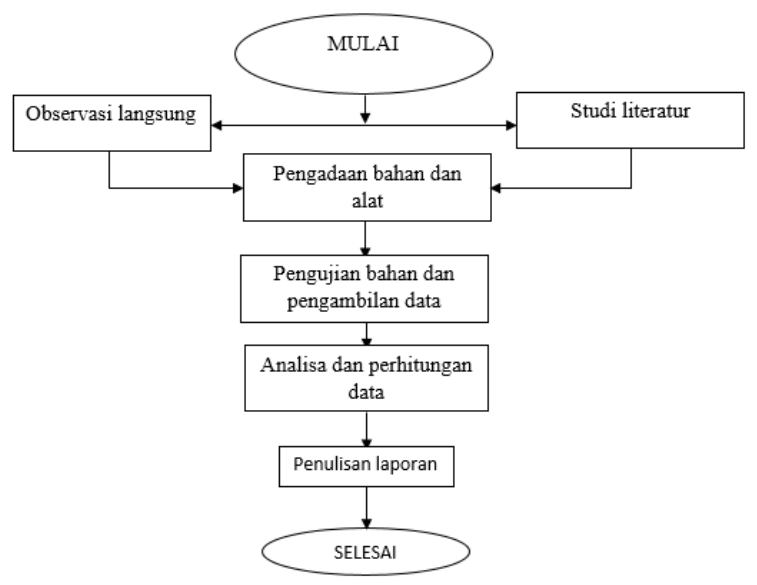

Gambar 1. Flowchart penelitian

Survei dilakukan dengan cara mengamati proses pembubutan yang selama ini dikerjakan pada baja st41.

2. Studi literature

Perencanaan pengamatan ini berdasarkan literature yang mempunyai hubungan dengan masalahan yang akan dihadapi, baik, jurnal, buku teks penelitian dan lain-lain, hal ini ditujukan untuk mendapatkan data mengenai segala hal yang relevansi dengan proses bubut pada baja st 41 .

3. Pengadaan bahan dan alat

Dalam tahap ini dilakukan pengadaan alat untuk memenuhi kebutuhan saat dilakukan pengujian sehingga dapat dilakukan pengamatan yang maksimal. Alat dan bahan yang diperlukan adalah sebagai berikut :

1) Mesin Bubut

2) Bahan uji baja silinder (st41)

3) Pahat HSS

4) Alat ukur temperatur laser

5) Kamera smartphone (untuk mengambil gambar kondisi pahat)

6) Software Image J dan CorelDRAW X7

7) Alat ukur kekasaran Surface Roughness SJ210 4. Pengujian Bahan dan Pengambilan data.

Pengujian bahan dimaksudkan untuk mendapatkan data perbandingan efisiensi saat melakukan proses pembubutan baja st 41 , yang nantinya akan dilakukan pengambilan data dalam beberapa tahap.

\section{Pengujian I}

Pengujian pertama ini merupakan pengujian yang dilakukan pada saat proses pembubutan, Pengujian ini ditujukan untuk mengambil data temperatur pahat sebelum dan sesudah pembubutan yang dilakukan di beberapa variasi perlakuan, adapun tatacara pengujian ini adalah sebagai berikut:

1) Mencatat atau mengukur temperatur awal pahat, menggunakan alat ukur infrared thermometer.
2) Pasangkan benda kerja pada chuck dan memasang center putar pada kepala lepas untuk mengurangi getaran saat proses pembubutan.

3) Mengatur parameter pada mesin bubut sebelum proses pembubutan, parameternya adalah sebagai berikut:

a. Tipe mesin bubut: Konvensional

b. Tipe : : CQ6230

c. Daya motor $\quad: 1.2 \mathrm{Kw}$

d. Voltage $\quad: 380 \mathrm{~V}$

e. Gerak Makan : $0.058 \mathrm{~mm} /$ putaran

(konstan)

f. Putaran mesin $\quad: 540 \mathrm{RpM}$

g. Kedalaman potong : $0.2 \mathrm{~mm} 0.5 \mathrm{~mm} 1 \mathrm{~mm}$ dan $1.5 \mathrm{~mm}$

4) Melakukan pembubutan sesuai perencanaan, yaitu:

a. Melakukan pembubutan sebanyak 4 spesimen benda uji dengan kedalaman potong masing-masing $0.2 \mathrm{~mm}, 0.5 \mathrm{~mm}, 1 \mathrm{~mm}$ dan $1.5 \mathrm{~mm}$ pada setiap benda uji sepanjang $90 \mathrm{~mm}$ dengan jangka waktu 15 menit setiap benda uji, jika kecepatan gerak pahat adalah $0.058 \mathrm{~mm} /$ putaran atau jika dihitung per menit adalah $31.32 \mathrm{~mm} / \mathrm{min}$, maka waktu yang diperlukan setiap pemakanan dari titik awal ke jarak $90 \mathrm{~mm}$ adalah sekitar 3 menit, jadi setiap spesimen memerlukan 5 kali proses dari titik awal ke titik $90 \mathrm{~mm}$ untuk mencapai waktu 15 menit.

b. Melakukan pembubutan sebanyak 4 pcs benda uji dengan kedalaman potong masing-masing $0.2 \mathrm{~mm}, 0.5 \mathrm{~mm}, 1 \mathrm{~mm}$ dan $1.5 \mathrm{~mm}$ pada setiap benda uji sepanjang $90 \mathrm{~mm}$, dengan jangka waktu 30 menit setiap benda uji. jika kecepatan gerak pahat adalah $0.058 \mathrm{~mm} /$ putaran atau jika dihitung per menit adalah $31,32 \mathrm{~mm} / \mathrm{min}$, maka waktu yang diperlukan setiap pemakanan dari titik awal ke jarak $90 \mathrm{~mm}$ adalah sekitar 3 menit, jadi setiap spesimen memerlukan 10 kali proses dari titik awal ke titik $90 \mathrm{~mm}$ untuk mencapai waktu 30 menit.

5) Mencatat dan mengukur temperatur pahat setelah proses pembubutan baru selesai.

Pengujian II

Pengujian atau pengambilan data ini dimaksudkan untuk mengetahui kondisi atau keausan pada pahat setelah proses pembubutan, adapun tata cara pengambilan data pada pengujian ini adalah sebagai berikut:

a. Mengambil sample foto pada saat setelah selesai pembubutan pada setiap benda uji. 


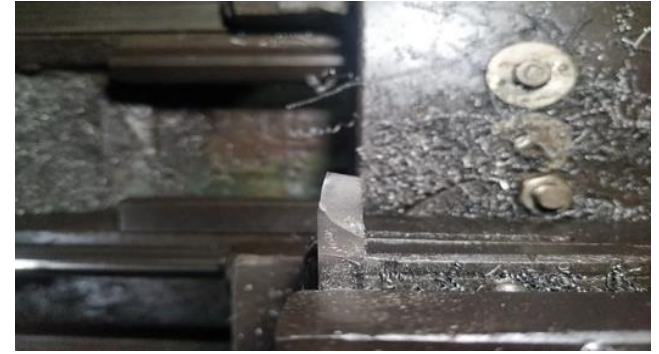

Gambar 2. Contoh sample foto kondisi pahat

b. Memasukkan sample foto pada software image J untuk diketahui skala asli dan skala pada gambar.

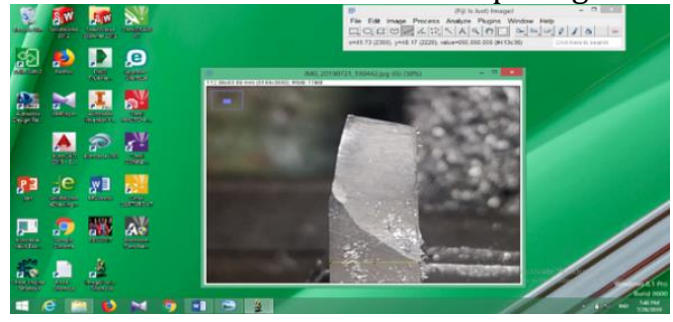

Gambar 3. Contoh foto kondisi pahat yang dimasukkan ke softwere Image J

c. Skala yang sudah diketahui pada image J kemudian dimasukkan pada softwere colerDraw X7 untuk diketahui ukuran keausan atau efek setelah pembubutan pada ujung pahat.

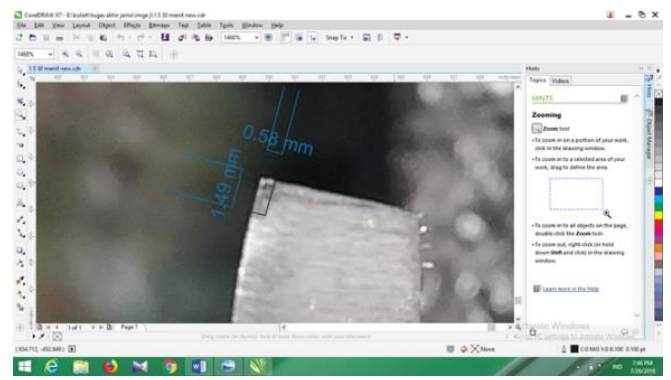

Gambar 4. Contoh foto perubahan kondisi pahat setelah diketahui ukurannya pada softwere CorelDraw X7

Pengujian III

Pengujian yang terakhir adalah pengujian kekasaran permukaan, pengujian ini digunakan pada 8 benda uji yang sudah melalui proses pembubutan dengan beberapa variasi diatas, adapun tahapan pengujian kekasaran ini adalah sebagai berikut:

a) Melakukan penandaan pada masing - masing benda uji dengan menggunakan menit waktu pembubutan dan angka kedalaman potong menggunakan spidol pada bagian yang tidak dilakukan proses uji kekasaran, waktu 15 menit ditandai dengan kode A dan 30 menit ditandai dengan kode $B$, sementara untuk kedalaman potong ditandai dengan kode sesuai angka kedalaman potong, contoh, benda uji pada kedalaman potong $0.2 \mathrm{~mm}$ dan proses pembubutan 15 menit ditandai dengan kode A0.2. b) Benda uji diletakkan pada tempat atau dudukan balok yang dibentuk $\mathrm{V}$ dengan menyesuaikan tinggi alat ukur dengan benda uji

c) Melakukan pengujian pada 8 benda uji diatas, pengujian setiap benda uji dilakukan masingmasing 2 titik pengujian

d) Melihat dan mencatat data yang tertera pada alat uji yang berupa angka digital, Data yang keluar tidak selalu sama pada 1 benda uji, untuk itu dilakukan 2 kali pengujian seperti yang tertera pada langkah pengujian ke-3.

e) Setiap benda uji dilakukan pengujian dengan cara yang sama.

f) Menghitung rata-rata dan membandingkan data yang didapat dari pengujian pada setiap benda uji, data yang didapat berguna sabagai grafik dan berguna sebagai acuan untuk melakukan analisa.

Setelah semua proses diatas dilakukan, maka selanjutnya adalah pembahasan dan analisa hasil dan dilanjutkan penulisan laporan.

\section{HASIL DAN PEMBAHASAN}

\section{Hasil pengujian I}

Berikut adalah hasil temperatur pahat setelah dilakukan pengukuran pada setiap variasi proses pembubutan pada tabel.

Tabel 1 Hasil pengukuran temperatur pahat

\begin{tabular}{|l|l|l|l|l|l|}
\hline R & KEDALA & \multicolumn{2}{|l|}{ 15 MENIT } & \multicolumn{2}{|l|}{ 30 MENIT } \\
\cline { 2 - 6 } $\mathbf{P}$ & MAN & T1 & T2 & T1 & T2 \\
M & POTONG & $\begin{array}{l}\text { T } \\
\left({ }^{\circ} \mathbf{C}\right)\end{array}$ & $\left({ }^{\circ} \mathbf{C}\right)$ & $\left({ }^{\circ} \mathbf{C}\right)$ & $\left({ }^{\circ} \mathbf{C}\right)$ \\
\hline \multirow{3}{*}{5} & $0,2 \mathrm{~mm}$ & 27,0 & 27,2 & 27,0 & 30,1 \\
\cline { 2 - 6 } & $0,5 \mathrm{~mm}$ & 27,0 & 28,0 & 27,0 & 30,5 \\
\cline { 2 - 6 } 4 & $1 \mathrm{~mm}$ & 27,0 & 28,9 & 27,0 & 31,0 \\
\cline { 2 - 6 } 0 & $1,5 \mathrm{~mm}$ & 27,0 & 29,8 & 27,0 & 31,5 \\
\hline
\end{tabular}

Hasil pengujian II

Pengujian ini menghasilkan efek burn pada pahat dengan dimensi yang berbeda setiap perlakuan, yang dapat dilihat pada tabel berikut

Tabel 2 Dimensi Efek Burn Pahat

\begin{tabular}{|c|c|c|c|c|}
\hline \multirow{2}{*}{$\begin{array}{l}\text { Kedalaman } \\
\text { Potong }\end{array}$} & \multicolumn{2}{|c|}{ Kondisi efek burn pahat (mm) } \\
\cline { 2 - 5 } & $\mathbf{1 5}$ menit & \multicolumn{2}{|c|}{ 30 menit } \\
\cline { 2 - 5 } & $\mathbf{P}$ & $\mathbf{L}$ & $\mathbf{P}$ & $\mathbf{L}$ \\
\hline 0.2 & 0.29 & 0.14 & 0.63 & 0.56 \\
\hline 0.5 & 0.30 & 0.18 & 0.64 & 0.48 \\
\hline 1 & 0.41 & 0.30 & 0.99 & 0.83 \\
\hline 1.5 & 0.48 & 0.40 & 1.49 & 0.58 \\
\hline
\end{tabular}

Hasil pengujian III

Penelitian ini merupakan penelitian untuk menguji tingkat kekasaran hasil pembubutan yang melibatkan dua faktor yaitu faktor jangka waktu 
pemmbubutan dan faktor kedalaman potong. Pengukuran kekasaran permukaan yang dilakukan dengan faktor variasi jangka waktu pembubutan (15 menit dan 30 menit) dan faktor berupa jumlah variasi kedalaman potong $(0.2 \mathrm{~mm}, 0.5 \mathrm{~mm}, 1 \mathrm{~mm}$, dan $1.5 \mathrm{~mm}$ ) yang pengkodeannya dapat dilihat pada tabel berikut:

Tabel 3 Kode spesimen uji

\begin{tabular}{|l|l|l|l|}
\hline \multirow{2}{*}{ NO } & \multirow{2}{*}{ KODE } & \multicolumn{2}{|l|}{ VARIASI } \\
\cline { 3 - 4 } & & $\begin{array}{l}\text { JANGKA } \\
\text { WAKTU }\end{array}$ & $\begin{array}{l}\text { KEDALAM } \\
\text { AN } \\
\text { POTONG }\end{array}$ \\
\hline 1 & A0.2 & 15 Menit & $0.2 \mathrm{~mm}$ \\
\hline 2 & A0.5 & 15 Menit & $0.5 \mathrm{~mm}$ \\
\hline 3 & A1 & 15 Menit & $1 \mathrm{~mm}$ \\
\hline 4 & A1.5 & 15 Menit & $1.5 \mathrm{~mm}$ \\
\hline 5 & B0.2 & 30 Menit & $0.2 \mathrm{~mm}$ \\
\hline 6 & B0.5 & 30 Menit & $0.5 \mathrm{~mm}$ \\
\hline 7 & B1 & 30 Menit & $1 \mathrm{~mm}$ \\
\hline 8 & B1.5 & 30 Menit & $1.5 \mathrm{~mm}$ \\
\hline
\end{tabular}

Dari pengujian III ini data yang didapat dinyatakan dengan angka Roughness Average (Ra), yang merupakan angka parameter kekasaran internasional, berikut adalah data yang didapat dari beberapa pengujian

写

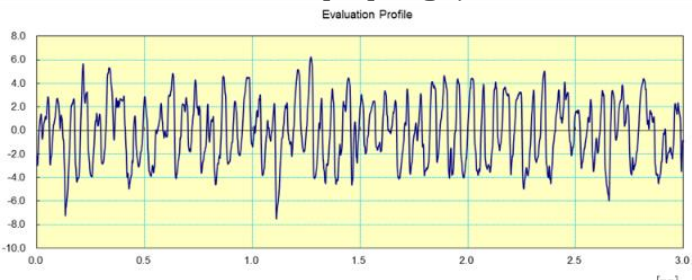

Gambar 5. Grafik kekasaran A0.2 di titik 1

马

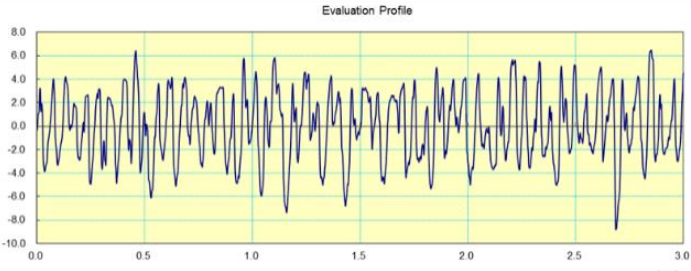

Gambar 6. Grafik kekasaran A0.2 di titik 2

Spesimen kode A0.2 di titik 1 mendapatkan nilai $\mathrm{Ra}=2.217 \mu \mathrm{m}$, dan di titik 2 mendapatkan nilai $\mathrm{Ra}=$ $2.406 \mu \mathrm{m}$, rata-rata $\mathrm{Ra}=2311 \mu \mathrm{m}$

?

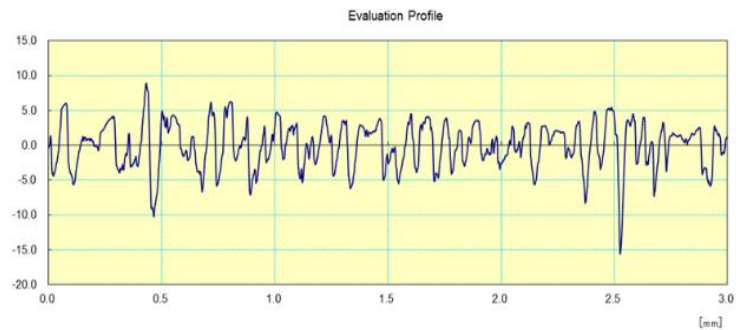

Gambar 7. Grafik kekasaran A0.5 di titik 1

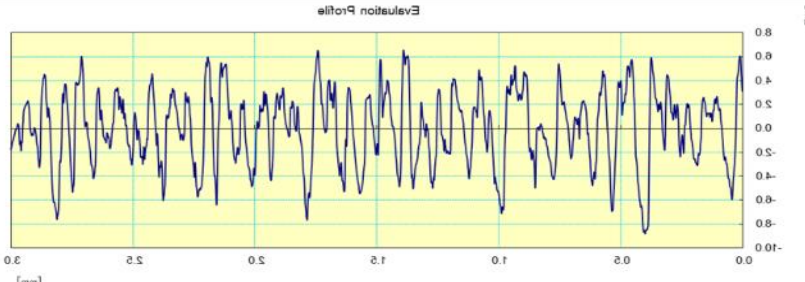

Gambar 8. Grafik kekasaran A0.5 di titik 2

Spesimen kode A0.5 di titik 1 mendapatkan nilai $\mathrm{Ra}=2.611 \mu \mathrm{m}$, dan di titik 2 mendapatkan nilai $\mathrm{Ra}=$ $2.596 \mu \mathrm{m}$, rata-rata $\mathrm{Ra}=2.603 \mu \mathrm{m}$.

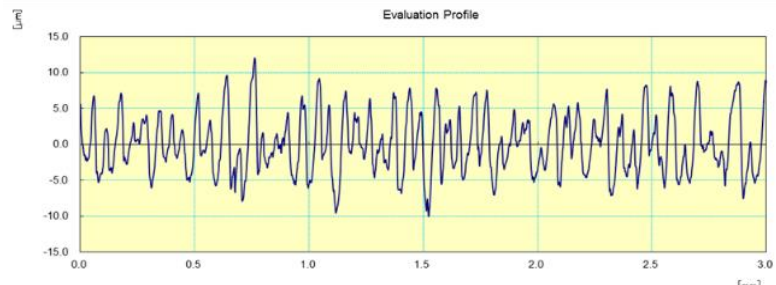

Gambar 9. Grafik kekasaran A1 di titik 1

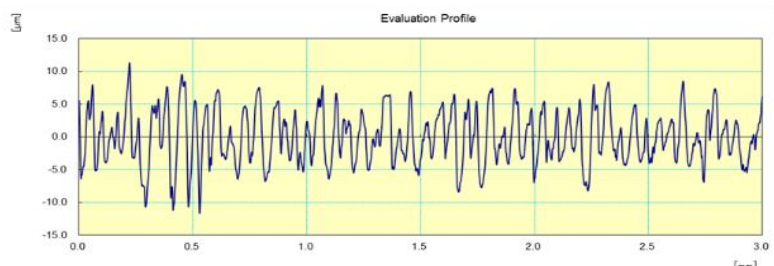

Gambar 10. Grafik kekasaran A1 di titik 2

Spesimen kode A1 di titik 1 mendapatkan nilai Ra= $3.305 \mu \mathrm{m}$, dan di titik 2 mendapatkan nilai $\mathrm{Ra}=$ $3.354 \mu \mathrm{m}$, rata-rata $\mathrm{Ra}=3.329 \mu \mathrm{m}$.

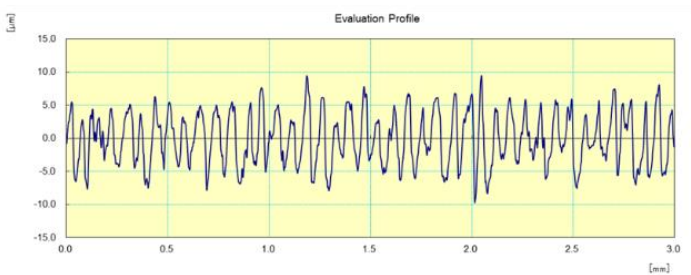

Gambar 11. Grafik kekasaran A1.5 di titik 1

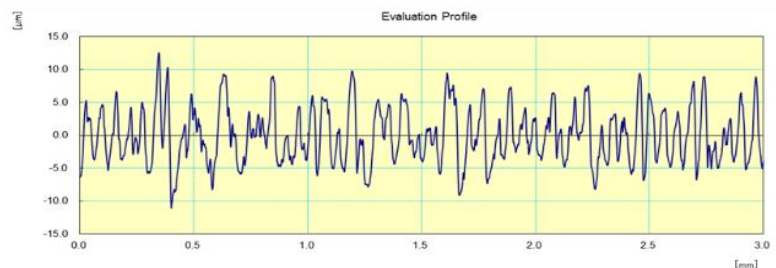

Gambar 12. Grafik kekasaran A 1.5 di titik 2

Spesimen kode A1.5 di titik 1 mendapatkan nilai $\mathrm{Ra}=3.397 \mu \mathrm{m}$ dan di titik 2 mendapatkan nilai $\mathrm{Ra}=$ $3.437 \mu \mathrm{m}$, rata-rata $\mathrm{Ra}=3.4 .5 \mu \mathrm{m}$. 


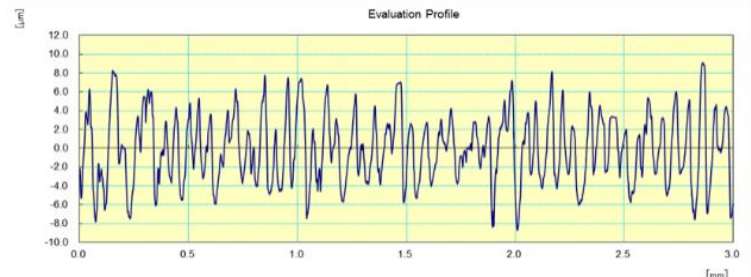

Gambar 13. Grafik kekasaran B0.2 di titik 1

Analisa Pengujian II

Analisa pengujian II adalah untuk membahas bagaimana perubahan kondisi pahat setelah dilakukan proses pembubutan, dari data-data yang sudah diketahui saat pengujian, penulis akan menganalisa bagaimana pengaruh variasi perlakuan terhadap kondisi pahat

Dari semua sampel foto kondisi pahat yang penulis amati, sebagian besar kondisi pahat setelah dilakukan proses pembubutan hanya mengalami perubahan warna pada bagian pahat yang aktif bersinggungan dengan benda uji, dan tidak terlihat adanya keausan, ada beberapa faktor yang mungkin mempengaruhi kondisi pahat tidak terjadi keausan yang signifikan bahkan tidak ada keausan, diantaranya adalah:

1. Rpm yang digunakan tidak terlalu tinggi.

2. Proses pembubutan yang tidak terlalu lama

3. Gerak pahat yang konstan dan stabil

4. St41 adalah baja luna

Walaupun keausan tidak terjadi pada pengujian ini, tetapi perubahan kondisi pada pahat yang mengalami efek burn atau perubahan warna akan mempengaruhi struktur kekasaran permukaan pahat dan akan mempengaruhi hasil dari pembubutan yang nanti akan dianalisa di pengujian III,

Dimensi efek burn yang terjadi pada pahat tidak sama setiap variasi pembubutan, berikut adalah grafik untuk mengetahui tingkat efek burn pada setiap perlakuan:

\section{DIMENSI EFEK BURN PADA}

PAHAT

- Bidang aktif pahat $\quad$ Lebar
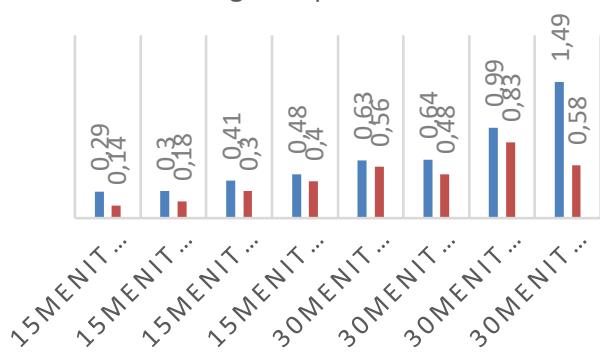

Gambar 22. Grafik perbandingan efek burn pahat setiap spesimen
Pada grafik diatas dimensi efek burn pada permukaan pahat berbeda-beda pada setiap perlakuan, itu menunjukkan variasi kedalaman potong dan jangka waktu pembubutan akan memepengaruhi kondisi pahat, pada tabel diatas menunjukkan semakin besar waktu dan kedalaman potong maka dimensi efek burn yang dihasilkan juga akan semakin besar, hal tersebut juga sejalan dengan pengujian temperatur pahat yang telah dilakaukan pada pengujian I, yang berarti semakin tinggi temperatur maka dimensi efek burn juga semakin besar.

\section{Penggujian III}

Analisa pengujian III ini ditujuakan untuk mengetahui pengaruh variasi kedalaman potong dan waktu pembubutan terhadap tingkat kekasaran permukan hasil pembubutan, Sebelum menganalisa hasil kekasaran, perlu dikaethui kecepatan pemotongan pada setiap spesimen untuk mengetahui apakah ada pengaruhnya terhadap hasil kekasaran.

Rumus kecepatan pemotongan

$\mathrm{V}=(\pi \cdot \mathrm{d} \cdot \mathrm{n}) / 1000$

Keterangan:

$\mathrm{V}$ : kecepatan pemotongan

$\mathrm{d}$ : diameter rata-rata

( (diameter awal+diameter akhir)/2)

$\mathrm{n}$ : kecepatan putaran spindel

1) Spesimen $A 0.2$

$\mathrm{V}=(3,14 \times 24.5 \mathrm{~mm} \times 540 \mathrm{Rpm}) / 1000$ $=41.54 \mathrm{~m} / \mathrm{min}$

2) Spesimen A0.5

$\mathrm{V}=(3,14 \times 23.75 \mathrm{~mm} \times 540 \mathrm{Rpm}) / 1000$

$=40.27 \mathrm{~m} / \mathrm{min}$

3) Spesimen $A 1$

$\mathrm{V}=(3,14 \times 22.5 \mathrm{~mm} \times 540 \mathrm{Rpm}) / 1000$ $=38,15 \mathrm{~m} / \mathrm{min}$

4) Spesimen $A 1.5$

$\mathrm{V}=(3,14 \times 21.25 \mathrm{~mm} \times 540 \mathrm{Rpm}) / 1000$ $=36,03 \mathrm{~m} / \mathrm{min}$

5) Spesimen B0.2 $\mathrm{V}=(3,14 \times 24 \mathrm{~mm} \times 540 \mathrm{Rpm}) / 1000$ $=40,69 \mathrm{~m} / \mathrm{min}$

6) Spesimen B0.5 $\mathrm{V}=(3,14 \times 22.5 \mathrm{~mm} \times 540 \mathrm{Rpm}) / 1000$ $=38,15 \mathrm{~m} / \mathrm{min}$

7) Spesimen B1 $V=(3,14 \times 20 m m \times 540 \mathrm{Rpm}) / 1000$ 


$$
=33,91 \mathrm{~m} / \mathrm{min}
$$
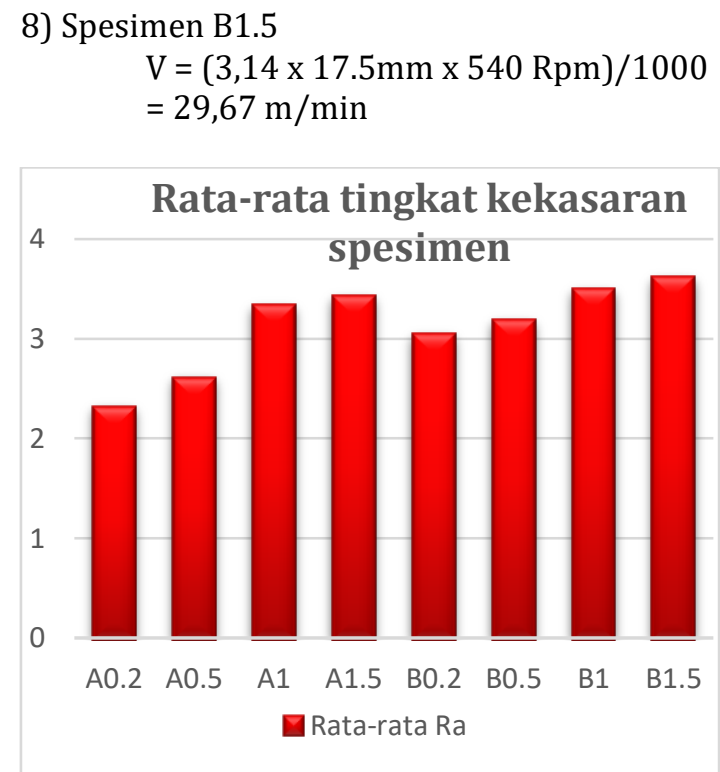

Gambar 23. Grafik perbandingan rata-rata Ra setiap spesiman

Dari grafik nilai Ra yang paling rendah atau spesimen dengan tingkat kekasaran paling halus adalah spesimen dengan kode A0.2, dan nilai Ra yang paling tinggi atau spesimen dengan tingkat kekasaran yang paling kasar adalah spesimen dengan kode B1.5.

Spesimen A0.2 menggunakan variasi kedalaman potong dan jangka waktu pembubutan yang paling rendah, yaitu menggunakan kedalaman potong 0.2 $\mathrm{mm}$ selama 15 menit, sedangkan spesimen B1.5 merupakan spesimen dengan variasi yang paling besar, yaitu dengan kedalaman potong $1.5 \mathrm{~mm}$ selama 30 menit.

Dari penjelasan di atas dapat diketahui bahwa kedalaman potong dan lamanya proses pembubutan akan mempengaruhi hasil dari kekasaran permukaan, semakin kecil menggunakan kedalaman potong, maka akan semakin kecil nilai $\mathrm{Ra}$ atau semakin halus tingkat kekasaran yang dihasilkan, semakin besar menggunakan kedalaman potong maka semakin besar nilai Ra atau semakin kasar tingkat kekasaran yang dihasilkan, hal ini bisa dilihat pada grafik dimana nilai Ra yang semakin meningkat apabila besar kedalaman potong juga meningkat.

Lamanya proses pembubutan juga berpengaruh terhadap tingkat kekasaran, dari grafik menunjukkan pada kedalaman potong yang sama dengan waktu yang berbeda tingkat kekasaran akan berbeda, semakin besar waktu yang digunakan maka hasil akan semakin kasar, namun yang paling berpengaruh adalah kedalaman potong, hal ini bisa dilihat pada spesimen A1 dan B0.2, A1 yang menggunakan kedalaman potong $1 \mathrm{~mm}$ tingkat kekasarannya atau Ra lebih tinggi dari B0.2 yang menggunakan kedalaman potong $0.2 \mathrm{~mm}$ walaupun A1 menggugunakan variasi waktu yang lebih sebentar.

Pada kecepatan potong yang telah dihitung per spesimen hasil spesimen yang paling tinggi kecepatan potongnya adalah spesimen A0.2 dengan $41,54 \mathrm{~m} / \mathrm{min}$, dan yang paling rendah kecepatan potongnya adalah spesimen B1.5 dengan 29,67 $\mathrm{m} / \mathrm{min}$, spesimen A0.2 adalah spesimen dengan Ra yang paling rendah atau kekasaran yang paling halus, sementara B1.5 adalah spesimen dengan Ra yang paling tinggi atau kekasaran yang paling kasar, hal ini menunjukkan semakin tinggi kecepatan pemotongan maka hasil akan semakin halus.

\section{Kesimpulan}

Dari pengujian yang dilakukan yaitu Analisa pengaruh kedalaman potong dan lama waktu proses pembubutan terhadap temperatur pahat, kondisi pahat dan kekasaran permukaan baja st41 dapat diperoleh kesimpulan sebagai berikut:

Pengaruh kedalaman potong dan waktu pembubutan adalah semakin besar kedalam potong dan waktu pembubutan maka temperatur pahat semakin temperatur dan efek burn pahat yang dihasilkan akan semakin besar, hal tersebut dapat dilahat dari variasi perlakuan yang tertinggi, yaitu kedalaman potong $1.5 \mathrm{~mm}$ dengan waktu 30 menit menghasilkan temperatur yang tertinggi yaitu 31.5 ${ }^{\circ} \mathrm{C}$, dan juga dimensi efek burn yang paling besar yaitu sepanjang $1.49 \mathrm{~mm}$ dengan lebar $0.58 \mathrm{~mm}$.

Umur pahat yang paling optimal adalah pahat yang dimensi efek burnnya paling kecil, hal tersebut dapat diperoleh dari perlakuan kedalaman potong dan waktu proses pembubutan yang paling rendah, kondisi tersebut dapat dilihat dari variasi perlakuan kedalaman potong $0.2 \mathrm{~mm}$ dan waktu 15 menit.

Tingkat kekasaran terendah dihasilkan dari variasi perlakuan terrendah, yaitu kedalaman potong 0.2 mm dengan waktu 15 menit menghasilkan rata-rata Ra $2.311 \mu \mathrm{m}$, dan tingkat kekasaran yang tertinggi dihasilkan dari variasi perlakuan tertinggi yaitu kedalaman potong $1.5 \mathrm{~mm}$ dengan waktu 30 menit akan menghasilkan rata-rata Ra $3.609 \mu \mathrm{m}$.

\section{Saran}

Dalam pengerjaan tugas akhir masih terdapat kekurangan sehingga nantinya dapat menjadi bahan evaluasi dan dapat dikembangkan lebih baik lagi. Beberapa saran yang perlu diperhatikan untuk dapat mencapai hasil yang lebih baik, diantaranya :

Sebelum melakukan penelitian sebaiknya mempersiapkan segala sesuatunya dengan matang 
mulai dari mesin bubut sampai tempat melakukan pengujian kekasaran permukaan agar dalam penelitian lebih efisien.

Saat melakukan penelitian sebaiknya dilakukan secara seteliti mungkin agar mendapatkan hasil yang sebaik mungkin dengan mengutamakan keselamatan dan kesehatan kerja.

Untuk penelitian selanjutnya yang relevan sangat baik jika dianalisa faktor-faktor atau variabelvariabel lain seperti variasi jenis bahan yang mempengaruhi tingkat kekasaran permukaan setelah proses pembubutan baja ST 41 .

Penelitian ini diharapkan dapat sebagai awalan bagi peneliti lain yang akan mengadakan penelitian yang relevan di kemudian hari, diharapkan penelitian ini dijadikan sebagai masukan dan acuan dalam melakukan penelitian.

Bagi Program Studi S1 Teknik Mesin UMAHA diharapkan menyesuaikan dengan perkembangan dan kebutuhan teknologi khususnya mesin dan alat pengujian. Sehingga memudahkan peneliti atau mahasiswa dalam pengambilan pengujian untuk pengambilan data.

\section{DAFTAR PUSTAKA}

Abidin, Z. (2010). (2010). MEKANISME KEAUSAN PAHAT PADA PROSES PEMESINAN : SEBUAH TINJAUAN PUSTAKA Zaenal Abidin. 6(1), 9-16.

Afifah, Y. N. (2019). Analysis of Unsteady Magneto Hydro Dynamic ( MHD ) Nano Fluid Flow Past A Sliced Sphere Analysis of Unsteady Magneto Hydro Dynamic ( MHD ) Nano Fluid Flow Past A Sliced Sphere. IOP Conference Series: Materials Science and Engineering, 494, 012033. https://doi.org/10.1088/1757899X/494/1/012033

Hadimi. (2008). Pengaruh perubahan kecepatan pemakanan terhadap kekasaran permukaan pada proses pembubutan. 11(1), 18-28.

Mujiono. (2016). Pengaruh Kecepatan Putaran Spindel dan Kecepatan Pemakanan terhadap Kekasaran Permukaan Baja EMS 45 pada Proses End Milling Surface.

Prasetyo, E., D. Analisis keausan pahat terhadap kualitas permukaan benda kerja pada proses pembubutan. 26-34.

Raul, D. (2016). (2016). POTONG PADA MESIN BUBUT TERHADAP TINGKAT KEKASARAN PERMUKAAN BENDA KERJA ST 41 Oleh: Jurnal Teknik Mesin, 24(1), 1-9.
Setiawan, A. C. (2011). Pengaruh variasi kecepatan putar mesin bubut dan sudut potong pahat terhadap kehalusan permukaan benda kerja hasil pembubutan tirus pada bahan st-60 Oleh : K 2500002 . 
J Nugroho / Mechonversio, Vol. 2, No.2, Desember 2019, 71-78

Halaman ini sengaja dikosongkan 